\title{
A Support for Affinity Chromatography That Covalently Binds Amino Groups via a Cleavable Connector Arm ${ }^{1}$
}

\author{
PRATAP SINGH, SIDNEY D. LEWIS, AND JULES A. SHAFER ${ }^{2}$ \\ Department of Biological Chemistry, The University of Michigan, Ann Arbor, Michigan 48109
}

Received October 11, 1978

\begin{abstract}
The preparation of a new succinimidyl ester agarose derivative (SEPE-Agarose) is described. This agarose derivative can be used for covalently linking proteins and other ligands containing amino groups to agarose via phenyl ester linkages that can later be broken under mild conditions which should not alter other groups which may be present in proteins such as cystinyl residues and glycosyl residues. SEPE-Agarose is prepared by the reaction of bis[4-[2-( $N$-succinimidoxycarbonyl)ethyl]phenyl] succinate with an aminoethylcarbamylmethyl derivative of agarose. Studies of the covalent binding and release of trypsin and myoglobin to SEPE-Agarose indicate that gels containing 0.1 to $0.6 \mu \mathrm{mol}$ protein $/ \mathrm{ml}$ of gel are obtained by reacting protein $(0.5-5 \mathrm{mg} / \mathrm{ml})$ with the $N$-succinimidyl ester groups in SEPE-Agarose. Protein-linked gel is reasonably stable in dilute phosphate buffers ( $\mathrm{pH} \leq 7.4, \leq 25^{\circ} \mathrm{C}$ ). Protein is released from the gel, however, by treatment at $25^{\circ} \mathrm{C}$ with solutions containing nucleophiles such as $1 \mathrm{M}$ imidazole-glycine, $\mathrm{pH} 7.4$, for $4 \mathrm{~h}$, or $1 \mathrm{M}$ hydroxylamine, $\mathrm{pH} 7$, for $10 \mathrm{~min}$. Protein is also released from the gel by treatment with $1 \mathrm{M}$ Tris $\mathrm{pH} 8.2$ for $24 \mathrm{~h}$. SEPE-Agarose should prove useful in affinity chromatography and immunoabsorption when it is difficult or impractical to elute material bound to conventional affinity supports.
\end{abstract}

Elution of absorbed material usually is a problem in affinity chromatography and immunoabsorption when the absorbed material interacts very strongly with the immobilized ligand. This problem often arises because material absorbed on a support is in an environment containing a high local concentration of immobilized ligand. Thus, it is more difficult to dissociate a complex between absorbed material and immobilized ligand than it is to break an analo- gous complex in solution. One way to remove strongly absorbed material from the support would be to break the linkage between the immobilized ligand and the support, and thereby remove the entire complex from the gel. Well-established methods (e.g., dialysis, ion-exchange chromatography, etc.) could then be used to dissociate the complex. In this work, we describe the preparation of an $N$-succinimidyl esteractivated agarose support (SEPE-Agarose) ${ }^{3}$ for covalently linking proteins and other

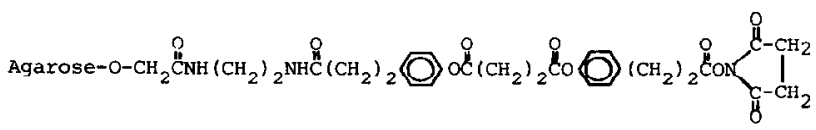

\section{SEPE-Agarose}

\footnotetext{
1 Financial support for this work from National Institutes of Health Research Grants AI 12625 and CA 24439 is gratefully acknowledged. A preliminary report of this work was presented at the 176th ACS National Meeting, Miami Beach, Florida, Biological Chemistry Section Abstract No. 19.

${ }^{2}$ To whom inquiries should be addressed.
}

${ }^{3}$ Abbreviations used: AECM-Agarose, aminoethylcarbamylmethyl agarose; BSPS, bis[4-[2-( $N$-succinimidoxycarbonyl)ethyl]phenyl] succinate; DCC, $N, N^{\prime}$-dicyclohexylcarbodiimide; DCU, $N, N^{\prime}$-dicyclohexylurea; DNFB, 2,4-dinitrophenylfluorobenzene; HPPA, 3-(4-hydroxyphenyl)propionic acid; NHS, $N$-hydroxysuccinimide; SEPE-Agarose, the $N$-suc- 
ligands containing amino groups to agarose via phenyl ester linkages which later can be broken. The phenyl ester linkage has an advantage over other cleavable linkages commonly used in crosslinking agents such as the disulfide [e.g., (1)], the diazo, and vicinal hydroxyl linkages [e.g., (2)] in that it can be cleaved under conditions that don't result in reduction of disulfide bonds or the oxidation of glycosyl residues which are present in many proteins.

\section{MATERIAL AND METHODS}

Myoglobin (horse heart) was obtained from Sigma Chemical Company. Diphenyl succinate was prepared according to the procedure of Daub and Johnson (3). Dinxane (Fisher, reagent grade) was dried by passage through a column of WN-3 activity grade 1 neutral alumina from Sigma (4). Redistilled solvents and silica gel-coated plastic sheets (Polygram SILG/UV $\mathrm{UV}_{254}$ from Brinkmann Instruments) were used for tlc unless otherwise specified. 3-(4-Hydroxyphenyl)propionic acid (HPPA) and $N$-hydroxysuccinimide (NHS) were obtained from Aldrich Chemical Company. Before use, HPPA and NHS were recrystallized from ethyl acetate-petroleum ether and ethyl acetate, respectively. $N$-Succinimidyl 3-(4-hydroxyphenyl)propionate (SHP) was prepared by condensing NHS and HPPA according to the method of Rudinger and Ruegg (5). Imidazole obtained from Aldrich Chemical Company was recrystallized three times from benzene and sublined under reduced pressure $\left[\mathrm{mp} 88-89^{\circ} \mathrm{C}\right.$ (corr), lit. (6) $\left.90.2-90.6^{\circ} \mathrm{C}\right]$.

Imidazole-glycine buffer was prepared by neutralizing a solution of imidazole and glyeine with concentrated $\mathrm{HCl}$ so that the final $\mathrm{pH}$ was 7.4 and the final total concentrations of imidazole and glycine were each $1 \mathrm{M}$. Hydroxylamine solutions were prepared just prior to use by neutralizing a solution of hydroxylamine- $\mathrm{HCl}$ with $4 \mathrm{M} \mathrm{NaOH}$ so that the resulting solution was $\mathrm{pH} 7.0,1 \mathrm{M}$ total hydroxylamine.

Bis [4-[2-(N-succinimidoxycarbonyl)ethyl]phenyl] succinate. BSPS was prepared by heating SHP $(2.63 \mathrm{~g}$, $10 \mathrm{mmol}$, which had been dried under reduced pressure at room temperature) with succinyl chloride $(0.57 \mathrm{ml}$, $5 \mathrm{mmol}$ ) in an oil bath at $140^{\circ} \mathrm{C}$ for $2 \mathrm{~h}$ (the molten

cinimidyl cster attached to agarose via phenyl ester linkages that is formed when BSPS reacts with AECMAgarose; protein-linked PE-Agarose, the agarose derivative formed when SEPE-Agarose reacts with protein; SHP, N-succinimidyl 3-(4-hydroxyphenyl)propionate; tlc, thin-layer chromatography; TNBS, 2,4,6-trinitrobenzenesulfonic acid; DNP, 2,4-dinitrophenyl. mass solidified after 10-30 min). Solvent was removed from a $\mathrm{CH}_{2} \mathrm{Cl}_{2}$ extract of the reaction product, and the resulting residue was extracted with $25 \mathrm{ml}$ of hot ethyl acetate. The material insoluble in ethyl acetate was recrystallized by adding ether to $\mathrm{a}_{2} \mathrm{CH}_{2} \mathrm{Cl}_{2}$ solution of the residue until the solution became distinctly cloudy. The solution was allowed to crystallize at room temperature. Three such crystallizations gave $0.41 \mathrm{~g}$ of crystalline material, mp $185-88^{\circ} \mathrm{C}$ (corr). This material showed a single yellow spot on tlc $\left(R_{f} 0.18\right)$ in benzene-ethyl acetate (6:4), 15-20 min after spraying the plate with $1 \% \mathrm{KMnO}_{4}$ in $10 \% \mathrm{Na}_{2} \mathrm{CO}_{3}$ (SHP gave a yellow spot, $R_{f} 0.29$, immediately after spraying with the $\mathrm{KMnO}_{4}$ reagent).

An additional $1.2 \mathrm{~g}$ of equally pure BSPS can be obtained by chromatography on silica gel of the material dissolved in the ethyl acetate and $\mathrm{CH}_{2} \mathrm{Cl}_{2}-$ ether solutions. BSPS obtained by the above procedures was used for reactions with the gel. An analytically pure sample of BSPS was obtained by adding $5 \mathrm{ml}$ of ether to $5 \mathrm{ml}$ of $\mathrm{CH}_{2} \mathrm{Cl}_{2}$ containing approximately $90 \mathrm{mg}$ of BSPS. After about $1 \mathrm{~h}$ at $4^{\circ} \mathrm{C}, 40 \mathrm{mg}$ of BSPS (mp $194-96^{\circ} \mathrm{C}$, corr) crystallized from the solution. The melting point of this material did not change upon further recrystallization from $\mathrm{CH}_{2} \mathrm{Cl}_{2}$-ether (1:1). Infrared spectrum (KBr, 1820, 1788, 1738, $\left.1509 \mathrm{~cm}^{-1}\right)$. ${ }^{1} \mathrm{H}$-nmr spectrum $\left(60 \mathrm{MHz}, \mathrm{CDCl}_{3}\right.$-trifluoroacetic acid $) \delta 7.2(8 \mathrm{H}, \mathrm{q}, J=4.5 \mathrm{~Hz}$, aromatic $\mathrm{H}), 3.0(20 \mathrm{H}$, $\mathrm{m},-\mathrm{CH}_{2}$ ).

Anal. caled for $\mathrm{C}_{30} \mathrm{H}_{28} \mathrm{~N}_{2} \mathrm{O}_{12}$ (608.57): C, 59.21; H, 4.64; N, 4.60. Found: C, 59.47; H, 4.67; N, 452 .

Aminoethylcarbamylmethyl Agarose (AECMAgarose). CM-Sepharose CL-6B (100 ml) which had been washed with $0.1 \mathrm{M} \mathrm{HCl}$ and water was activated with $6.9 \mathrm{~g}(60 \mathrm{mmol}) \mathrm{NHS}$ and $12.4 \mathrm{~g}(60 \mathrm{mmol}) \mathrm{DCC}$ in $200 \mathrm{ml}$ of dioxane according to the procedure of Cuatrecasas and Parikh (4). The NHS-activated gel was suspended in $100 \mathrm{ml}$ of dioxane and shaken $90 \mathrm{~min}$ with $100 \mathrm{ml}$ of $1.0 \mathrm{M}$ ethylenediamine in $0.5 \mathrm{M}$ phosphate buffer at $\mathrm{pH}$ 8.0. The gel was removed by filtration and washed on a Büchner funnel with $0.1 \mathrm{M} \mathrm{NaCl}$ (ca. 4 liters) until the washings gave a negative TNBS test for amino groups (7). The gel was then treated with $\mathrm{NaOH}$ according to the procedure of Cuatrecasas and Parikh (4) for removing labile carboxyl groups. The resulting AECM-Agarose was then washed with water. This gel gave an orange TNBS test for amino groups and was stored under water at $4^{\circ} \mathrm{C}$.

$S E P E$-Agarose. A portion of the aqueous suspension of AECM-Agarose was filtered, washed four times with $50 \mathrm{ml} \mathrm{Me} \mathrm{MO}_{2} \mathrm{SO}$, and dried on a Büchner funnel under aspirator vacuum for $2 \mathrm{~min}$, and $3.5 \mathrm{~g}$ of the semidry gel was shaken for $4 \mathrm{~h}$ with $5 \mathrm{ml} \mathrm{Me} 2 \mathrm{SO}$ containing $0.3 \mathrm{~g}(0.49 \mathrm{mmol})$ BSPS. The gel was then separated by centrifugation from the BSPS solution and washed six times by shaking for $5 \mathrm{~min}$ each time with $20 \mathrm{ml} \mathrm{Me} 2 \mathrm{SO}$ in order to remove noncovalently bound BSPS and NHS. The gel was then washed with 
$10 \mathrm{ml}$ of $0.02 \mathrm{M} \mathrm{HCl}$ and shaken with $30 \mathrm{ml}$ of $0.02 \mathrm{M}$ $\mathrm{HCl}$ for $40 \mathrm{~min}$ in order to convert any unmodified amino groups to their unreactive protonated forms. The resulting gel was washed with water until the washings were neutral and then washed three times with $10 \mathrm{ml}$ dioxane. SEPE-Agarose so obtained gave a weakly positive TNBS test for amino groups and was stored under dioxane.

Succimmidyl ester linkages in SEPE-Agarose. These linkages were determined by reacting the gel with glycine and estimating the amount of NHS released from the absorbance of the conjugate base of NHS at $260 \mathrm{~nm}\left(\epsilon 10,000 \mathrm{M}^{-1} \mathrm{~cm}^{-1}\right)$. As expected, the absorbance at $260 \mathrm{~nm}$ disappeared when the NHS solution was acidified to $\mathrm{pH} \mathbf{3 . 0}$.

The 3-(4-hydroxyphenyl)propionyl content of $S E P E$-Agarose. SEPE-Agarose $(50 \mu \mathrm{l})$ was hydrolyzed for $16 \mathrm{~h}$ in a stirred solution of $5 \mathrm{M} \mathrm{NaOH}$ in an evacuated sealed tube immersed in an oil bath at $110^{\circ} \mathrm{C}$. The amount of HPPA released on hydrolysis was determined from the absorbance of the HPPA $\left(\epsilon_{295}\right.$ $2.35 \times 10^{3} \mathrm{M}^{-1} \mathrm{~cm}^{-1}$ ) in an aliquot of the hydrolysate, after the hydrolysate had been diluted into $0.1 \mathrm{M}$ $\mathrm{NaOH}$ and clarified by centrifugation. Separate experiments wherein HPPA was added to the gel prior to hydrolysis indicated a $98 \%$ recovery of the HPPA from the hydrolysate.

Reaction of SEPE-Agarose with proteins. Packed SEPE-Agarose $(0.3 \mathrm{ml})$ was washed three times with $3 \mathrm{ml}$ of ice-cold $0.1 \mathrm{M}$ phosphate buffer ( $\mathrm{pH} \mathrm{7.0)}$ and then stirred with $4 \mathrm{ml}$ of a protein solution in $0.1 \mathrm{M}$ phosphate buffer (pH 7.4) at $25^{\circ} \mathrm{C}$. After 2 to $4 \mathrm{~h}$, the gel was washed with $1 \mathrm{M}$ phosphate buffer $(\mathrm{pH}$ 7.4) until washings showed no protein absorption at $280 \mathrm{~nm}$ (4-10 washings of $3 \mathrm{ml}$ ). When trypsin was the protein, noncovalently linked protein was removed by additional washing of the gel twice with $4 \mathrm{ml}$ of $2 \mathrm{M}$ guanidinium hydrochloride and twice with $3 \mathrm{ml}$ of $1 \mathrm{M}$ phosphate buffer ( $\mathrm{pH}$ 7.4). Unreacted succinimidyl ester linkages on the gel were removed by reacting the gel with $4 \mathrm{ml}$ of $1 \mathrm{M}$ glycine ( $\mathrm{pH}$ 7.4) for $30 \mathrm{~min}$. The resulting protein-linked phenyl ester agarose (protein-linked PE-Agarose) was washed twice with $3 \mathrm{ml}$ of $1 \mathrm{M}$ phosphate buffer ( $\mathrm{pH} \mathrm{7.4)}$ and stored under water at $4^{\circ} \mathrm{C}$.

The binding of protein to SEPE-Agarose. Protein binding was monitored by determining the decrease in protein concentration of the protein solution upon its reaction with the gel. The concentration of trypsin in solutions was determined from measurements of catalytic activity (see below) and/or absorbance at $280 \mathrm{~nm}$ of an acidified ( $\mathrm{pH} \mathrm{3}$ ) sample of the solution. (The trypsin solution was acidified to eliminate the contribution of NHS to the absorbance.) The concentration of myoglobin in solution was determined from the absorbance at $410 \mathrm{~nm}$. Gel-bound protein was also determined directly from the amino acid content [amino acid analysis (8) of the washed gel after acid hydrolysis].
Tryptic activity. Enzymatic activity of dissolved trypsin was determined by the procedure of Erlanger et al. (9) except that $\alpha-N$-benzoyl-L-arginine $p$-nitroanilide hydrochloride was used as substrate instead of the DL-derivative, and the assay buffer was prepared by diluting $9.6 \mathrm{mg}$ substrate in $0.5 \mathrm{ml} \mathrm{Me} 2 \mathrm{SO}$ with $110 \mathrm{ml} 0.1 \mathrm{M}$ phosphate buffer $(\mathrm{pH} 7.4)$ and $19.8 \mathrm{ml}$ water. In order to determine the catalytic activity of trypsin linked to gels, 20 to $50 \mu$ l of the gel was combined with $0.1 \mathrm{ml}$ Sepharose CL-6B. (Small volumes of gel were transferred from a buffer-diluted suspension of the gel.) After washing the combined gel with $1 \mathrm{ml} 0.1 \mathrm{M}$ phosphate buffer ( $\mathrm{pH} \mathrm{7.4),} \mathrm{the}$ gel was centrifuged and the gel pellet suspended in $5 \mathrm{ml}$ of assay buffer at $25^{\circ} \mathrm{C}$. The gel suspension was stirred (magnetic stirrer) in a water bath $\left(25^{\circ} \mathrm{C}\right)$ consisting of a jacketed beaker through which water from a constant-temperature bath $\left( \pm 0.1^{\circ} \mathrm{C}\right)$ was circulated. At the end of appropriate time intervals (1-5 min), the assay mixture was centrifuged in order to stop the reaction, and the absorbance $(410 \mathrm{~nm})$ of the supernatant solution measured. The supernatant solution was returned to the tube containing the gel and stirring continued. Enzymatic activities were determined from slopes of the linear plots of absorbance versus time of stirring.

The release of protein from protein-linked $P E$ Agarose. Release of protein was monitored by determination of the increase in soluble protein and/or the decrease in gel-bound protein upon stirring 0.1 to $0.3 \mathrm{ml} \mathrm{gel} \mathrm{with} 1$ to $5 \mathrm{ml}$ of buffer. Gel-bound protein was determined from the amino acid content (after acid hydrolysis) of the gel. Dissolved protein was determined from the absorbance, enzymatic activity (after correction for inactivation, $<20 \%$, of the trypsin upon standing in the buffer used in the release reaction), and/or the amino acid content (after acid hydrolysis) of aliquots of solutions which had been stirred with the gel. HPPA $\left(\lambda_{\max } 275 \mathrm{~nm}, \epsilon 1.4\right.$ $\times 10^{3} \mathrm{M}^{-1} \mathrm{~cm}^{-1}$ ) and $N$-3-(4-hydroxyphenyl)propionylglycine also were released from the gel along with the protein, which itself is released with 3-(4-hydroxyphenyl)propionyl groups linked to some of its amino groups. In order to calculate from the uv spectrum the amount of trypsin present in the supernatant solution, simultaneous equations were solved utilizing absorbance measurements at 280 and $290 \mathrm{~nm}$, assuming the absorptivities at 280 and $290 \mathrm{~nm}$ for the hydroxyphenylpropionyl derivatives were equal to that observed for HPPA. The amount of myoglobin in the supernatant imidazole-glycine buffer was determined from the absorbance of the solution at $410 \mathrm{~nm}$ (where the absorbance of HPPA is negligible) using the separately determined molar absorptivity of myoglobin $\left(1.55 \times 10^{5} \mathrm{M}^{-1} \mathrm{~cm}^{-1}\right)$ in the imidazoleglycine buffer.

Determination of the number of connector arm linkages to trypsin. Trypsin was released from the gel with $1 \mathrm{M}$ hydroxylamine ( $\mathrm{pH} 7,10 \mathrm{~min})$. The re- 
sulting solution was adjusted to $\mathrm{pH} 3$ and dialyzed against $1 \mathrm{~mm} \mathrm{HCl}$ in order to remove hydroxylamine and other low molecular weight components. The resulting protein solution was dinitrophenylated using a method similar to that described by FraenkelConrat et al. (10). The acid-hydrolyzed dinitrophenylated protein was extracted with ether. The ether-insoluble fraction (mainly unmodified amino acids) was subjected to amino acid analysis for determination of the recovery of protein and the lysine content. The yield of free lysine gave the number of lysyl $\epsilon$-amino groups which were bonded to the connector arm and therefore not dinitrophenylated. The content of $\alpha$-DNP amino acids in the hydrolysate was determined by treating the ether extract by a method similar to that of Stevens (11) to remove DNP-OH, $\mathrm{DNP}-\mathrm{NH}_{2}$ and other artifacts, except that a thinlayer plate (Prekotes Silica Gel G from Applied Science Laboratories) was used in place of the silicic acid column. The $\alpha$-DNP amino acids which remained at the origin were eluted from the silica gel plate with 4\% acetic acid in chloroform. After removal of the eluant under reduced pressure, $\alpha$-DNP amino acids were taken up in $1 \% \mathrm{NaHCO}_{3}$ and quantified from the uv spectrum of the solution (10).

Identification of NHS. NHS was identified as a product of hydroxylamine treatment of ligand-linked gels from its characteristic uv spectrum which disappears upon acidification ( $\mathrm{pH} \mathrm{3-4)}$ and from its behavior on tlc. In a typical experiment $0.3 \mathrm{ml}$ glycinelinked PE-Agarose was washed with $\mathrm{pH} 7.4 \quad 0.1 \mathrm{M}$ phosphate buffer. The observation that the washings were free of $260 \mathrm{~nm}$-absorbing material demonstrated the absence of NHS. The glycine-linked PE-Agarose was then treated with $4 \mathrm{ml}$ of $1 \mathrm{M}$ hydroxylamine at $\mathrm{pH} 7.0$ for $10 \mathrm{~min}$. The uv spectrum of a sample of the hydroxylamine solution showed a maximum at $260 \mathrm{~nm}$. Upon acidification ( $\mathrm{pH} \mathrm{3}$ ) of the sample, there was a marked decrease in the uv spectrum. The amount of NHS in the sample was calculated from the absorbance change $(260 \mathrm{~nm})$ observed upon acidification and a value of $10,000 \mathrm{M}^{-1} \mathrm{~cm}^{-1}$ for the corresponding change in molar absorptivity observed for NHS. The amount of NHS so calculated was increased by $14 \%$ in an attempt to correct for decomposition (1.4\% per min) of NHS in the $1 \mathrm{M}$ hydroxylamine solution. In the acidified sample, an absorption band with a maximum at $275 \mathrm{~nm}$ was distinguishable. This absorbance band which prior to acidification was masked by the NHS spectrum is attributed to the presence of HPPA and derivatives thereof that were liberated from the gel by hydroxylamine. After a 10-min treatment with $1 \mathrm{M}$ hydroxylamine, another 0.3-ml sample of glycine-linked PE-Agarose was acidified to $\mathrm{pH} 4$ and extracted three times with $5 \mathrm{ml}$ of ethyl acetate. The combined ethyl acetate extracts were dried over anhydrous sodium sulfate. The residue obtained after evaporation of the ethyl acetate under reduced pressure, exhibited the same
$R_{f}$ on tlc as that of authentic NHS (benzene:dioxane: acetic acid, 20:6:2, and chloroform:ethanol, 9:1).

\section{RESULTS AND DISCUSSION}

As expected from previous studies of an NHS derivative of agarose (4), amines rapidly displace NHS from SEPE-Agarose and become covalently linked to the solid support via amide bonds. Figure 1 illustrates the time course of the reaction of SEPE-Agarose with $0.1 \mathrm{~m}$ glycine at $\mathrm{pH}$ 7.4. This reaction is essentially complete within 30 to $60 \mathrm{~min}$ as indicated by the cessation of release of NHS. Although water also attacks gel-bound succinimidyl ester, at $\mathrm{pH} 7.4$ hydrolysis of the succinimidyl ester is much slower than reaction with glycine, and release of NHS is not complete even after $6 \mathrm{~h}$ at $\mathrm{pH} 7.4$ in the absence of glycine (Fig. 1).

The time course of the binding of a protein (myoglobin) to SEPE-Agarose is depicted in Fig. 2. The decrease in incorporation of myoglobin accompanying the decrease in myoglobin concentration shown in Fig. 2 probably is due in part to the decreased ability of the myoglobin reaction to compete favorably with hydrolysis of the succinimidyl ester. Control experiments (Table I) wherein the gel-bound succinimidyl ester was decomposed by treatment with glycine prior to reaction with myoglobin showed little myoglobin binding ( $<7 \%$ of the experimental gel, Table I). Furthermore, the protein content of myoglobin-linked PE-

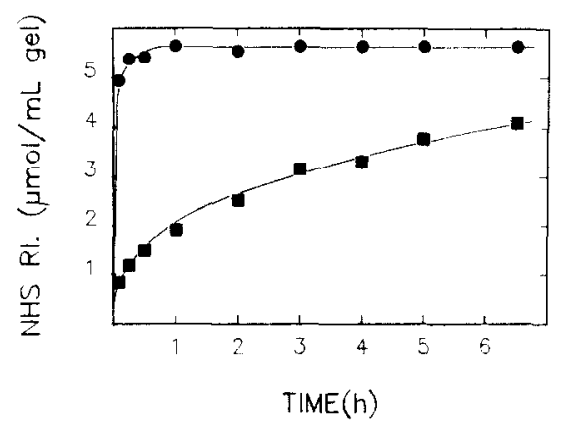

FIG. 1. Glycine-mediated release of NHS from SEPE-Agarose $\left(25^{\circ} \mathrm{C}\right)$. The amount of NHS released (NHS Rl.) in the presence (O) and absence ( $\square$ ) of $0.1 \mathrm{M}$ glycine in $0.1 \mathrm{M}$ phosphate buffer at $\mathrm{pH} 7.4$ was determined from the absorbance $(260 \mathrm{~nm})$ of samples of the centrifuged reaction mixture. 


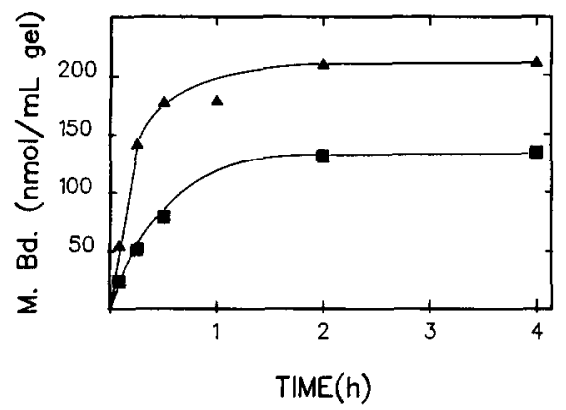

FIG. 2. Time dependence of the binding of myoglobin to SEPE-Agarose upon its reaction in a $0.1 \mathrm{M}$ phosphate-buffered $\left(\mathrm{pH} 7.4,25^{\circ} \mathrm{C}\right)$ solution at the following concentrations of myoglobin: 0.5 ( $\square$ ) and $2(\Lambda) \mathrm{mg} / \mathrm{ml}$. The amount of myoglobin bound to the gel (M. Bd.) was determined from the decreased absorbance $(410 \mathrm{~nm})$ of samples of the centrifuged reaction mixture.

Agarose, as determined by amino acid analysis of the acid-hydrolyzed gel, was not changed significantly $(<10 \%)$ by extensive washing of the gel. These data are consistent with the view that there is little noncovalent binding of myoglobin to the gel.

The data in Table I for trypsin, however, indicate a greater noncovalent binding of trypsin to glycine-inactivated gel than that seen for myoglobin. Additionally, as shown in Table $I$, the amount of trypsin which appears to bind to SEPE-Agarose as judged by the decrease in absorbance of the reaction mixture $(730 \mathrm{nmol} / \mathrm{ml}$ gel with $5 \mathrm{mg} / \mathrm{ml}$ trypsin and $350 \mathrm{nmol} / \mathrm{ml}$ gel with $1 \mathrm{mg} / \mathrm{ml}$ trypsin) is larger than the amount of trypsin on the gel after extensive washing as judged by amino acid content of the gel after acid hydrolysis $(440 \mathrm{nmol} / \mathrm{ml}$ gel and $220 \mathrm{nmol} / \mathrm{ml}$ gel for gels that had been reacted with $5 \mathrm{mg} / \mathrm{ml}$ and $1 \mathrm{mg} / \mathrm{ml}$ trypsin, respectively). The data in Table I indicate that trypsin-linked PE-agarose noncovalently absorbs more soluble trypsin than glycinelinked PE-Agarose. The reason for the difference was not explored. Separate experiments, however, indicate that such noncovalently bound protein is easily removed

\section{TABLE I}

Binding and Release Reactions of Myoglobin and Trypsin with SEPE-Agarose

\begin{tabular}{|c|c|c|c|c|c|c|c|}
\hline \multirow{2}{*}{$\begin{array}{c}\text { Protein } \\
\text { concentration } \\
(\mathrm{mg} / \mathrm{ml})\end{array}$} & \multicolumn{2}{|c|}{$\begin{array}{c}\text { Amount } \\
\text { incorporated } \\
(\mathrm{nmol} / \mathrm{ml} \text { gel })^{\alpha}\end{array}$} & \multicolumn{2}{|c|}{$\begin{array}{c}\text { Amount } \\
\text { released }^{b} \\
\text { (nmol/ml gel) }\end{array}$} & \multicolumn{2}{|c|}{$\begin{array}{c}\text { Amount } \\
\text { remaining }^{c} \\
(\mathrm{nmol} / \mathrm{ml} \text { gel })\end{array}$} & \multirow{2}{*}{$\begin{array}{l}\text { Release }(\%) \text { of } \\
\text { covalently } \\
\text { bound protein }\end{array}$} \\
\hline & Expt & Control & Expt & Control & Expt & Control & \\
\hline \multicolumn{8}{|l|}{ Myoglobin } \\
\hline 2 & 210 & 14 & $180(210)$ & $<2(<4)$ & 10 & & $86-100^{d}$ \\
\hline 0.5 & 130 & 9 & 80 & 5 & & & $62^{d}$ \\
\hline \multicolumn{8}{|l|}{ Trypsin } \\
\hline 5 & 730 & 85 & $400(350)$ & (24) & 91 & 12 & $79-81^{e}$ \\
\hline 1 & 350 & 35 & (176) & 16 & 48 & & $79^{e}$ \\
\hline
\end{tabular}

a Determined from the decreased absorbance of the protein solution after reaction with the gel. The control gel was SEPE-Agarose which had been inactivated by reaction with $0.1 \mathrm{M}$ glycine in $0.1 \mathrm{M}$ phosphate buffer, $\mathrm{pH} 7.4$, for $16 \mathrm{~h}$ prior to reaction with protein.

${ }^{b}$ After reaction with the protein solutions, the gels were washed and reacted with $1 \mathrm{~m}$ imidazole-glycine buffer ( $\mathrm{pH}$ 7.4) until release of protein essentially ceased (4-6 h). Amounts were determined either from absorbance measurements of the supernatant solution or the amino acid content after acid hydrolysis, in parentheses.

$c$ Subsequent to treatment with imidazole-glycine buffer the gels were washed and acid hydrolyzed. Amounts were determined from the amino acid content of the gels after acid hydrolysis.

d Calculated (neglecting noncovalent absorption) from the ratio of the amount released (expt) and the amount incorporated (expt).

$e$ Calculated from the ratio of the amount released (expt) to the sum of the amount released (expt) and the amount remaining (expt). Separate hydrolysis of the gel prior to treatment with imidazole yielded values for trypsin content which were within $5 \%$ of the sum of the amount released and amount remaining. 
by washing the gel with $2 \mathrm{~m}$ guanidinium hydrochloride.

In the protein-linked gels, derived from SEPE-Agarose, the connector arm by which the protein is linked to the agarose matrix contains two phenyl ester linkages. Phenyl esters are much more susceptible than alkyl esters and amides to catalysis of their hydrolysis by nucleophilic reagents with $\mathrm{pK}$ 's in the range 5 to 10 . For example, imidazole is about 70,000 times more effective as a catalyst for the hydrolysis of phenyl acetate than for ethyl acetate (12). Although phenyl esters are generally more susceptible than alkyl esters to hydroxide ion-catalyzed hydrolysis, this increased susceptibility toward hydroxide ion is much less pronounced and varies with the aromatic substituents. Interestingly, hydroxide ioncatalyzed hydrolysis of phenyl acetate is only 11 times faster than that of ethyl acetate (12). The reactivity of the phenyl ester linkages present in the protein-linked PEAgarose should not be very different from that of $p$-methylphenyl acetate, which in turn is not very different from phenyl acetate in its reactivity (12). A buffer $1 \mathrm{M}$ in both imidazole and glycine (at $\mathrm{pH}$ 7.4) was used in this work to cleave phenyl ester linkages and release covalently bound protein from the agarose. Glycine was added to the imidazole buffer to ensure that acyl imidazoles formed as a result of nucleophilic attack on the phenyl ester would not react with amino groups in the protein.

The reactivity of the phenyl esters attached to the agarose was determined using glycine-linked PE-agarose which was prepared by reacting SEPE-Agarose with $0.1 \mathrm{M}$ glycine in $0.1 \mathrm{~m}$ phosphate buffer, $\mathrm{pH}$ 7.4. The time course of the release of 3-(4-hydroxyphenyl)propionyl-glycine and HPPA (derived from succinimidyl esters which were hydrolyzed prior to reaction with glycine) from glycine-linked PE-Agarose was followed by monitoring the appearance of absorbance at $275 \mathrm{~nm}$. In separate experiments, it was determined that the $1 \mathrm{M}$ glycine in the imidazole-glycine solution contributed little to the observed rate of phenyl ester hydrolysis. The data depicted in Fig. 3 indicate that the release of phenolic groups is not a monophasic process. Analysis of the data in Fig. 3 in terms of a biphasic reaction yields a rate constant of $0.064 \mathrm{~min}^{-1}$ (inset to Fig. 3) for the rapid reaction which accounts for $78 \%$ of the releasable groups. The expected pseudo-first-order rate con-

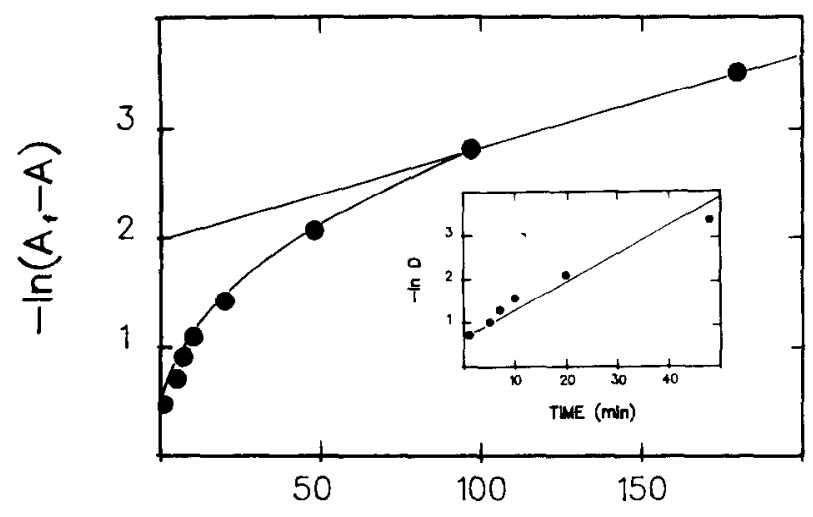

TIME (min)

FIG. 3. First-order plot for the release of HPPA and derivatives thereof from glycine-linked PEAgarose in $1 \mathrm{M}$ imidazole-glycine buffer $\left(\mathrm{pH} 7.4,25^{\circ} \mathrm{C}\right)$ as reflected by the increase in absorbance $(A)$ at $275 \mathrm{~nm} . A_{\mathrm{t}}$ represents the final absorbance of the reaction mixture at $275 \mathrm{~nm}$. The plot in the inset was constructed by graphically eliminating the slow process. This operation was accomplished by subtracting from values of $\left(A_{\mathrm{f}}-A\right)$ at various times, the corresponding values of $\left(A_{\mathrm{f}}-A\right)$ obtained from the line drawn for the slow process. The resulting differences, $D$, were taken as the values of $\left(A_{\mathrm{f}}-A\right)$ for the rapid process. 
stant for hydrolysis of $p$-methylphenyl acetate in $1 \mathrm{M}$ imidazole buffer at $\mathrm{pH} 7.4$ is $0.2 \mathrm{~min}^{-1}$ (13). Considering the difference in the structure of the resin-bound phenyl esters and $p$-methylphenyl acetate, the approximately 6.3 -fold $(0.2 \times 2 / 0.064)$ lower rate of release from that expected from the stability of $p$-methylphenyl acetate is not unreasonable. ${ }^{4}$ The failure of the hydrolysis of phenyl ester linkages on the gel to be cleanly monophasic may be caused by some of the phenyl ester linkages being in an environment wherein attack by imidazole is sterically hindered. ${ }^{5}$

The kinetics of release of protein from protein-linked PE-Agarose are complicated by the heterogeneous reactivity of the phenyl ester linkages on the gel and the possibility that protein is linked to the agarose via more than one connector arm. Qualitatively, one would expect the protein to be released from the gel at a rate which is lower than that of phenyl ester hydrolysis, since a bound protein molecule is not released from the gel until all of its linkages to the gel are broken. As shown in Fig. 4, this expectation is realized, wherein it can be seen that the fraction of releasable protein which appears in solution at a given time $\left(f_{\mathrm{r}}\right)$ is less than the extent of hydrolysis of the phenyl ester linkages $(x)$.

The extent of release of releasable protein from the gel at a given time should be related by $\mathrm{Eq}$. [1] to the extent of cleavage of connector arms. In Eq. [1], $f_{\mathrm{r}}$ represents the fraction of total releasable

$$
f_{\mathrm{r}}=\sum_{n=1}^{n=i} x^{n} f_{n}^{0}
$$

protein that is released when the fraction of gel-attached connector arms that are

\footnotetext{
${ }^{4}$ In order to estimate this factor, it was assumed that both phenyl ester linkages on the connector arm are hydrolyzed at equal rates and that when the substituted monophenyl succinate derivative is liberated from the gel it hydrolyzes to liberate the phenolic group of HPPA at a rate which is more rapid than hydrolysis of gel-linked phenyl esters.

${ }^{5}$ Deviations of the kinetics from that expected for a monophasic reaction might also arise from a failure of the assumptions stated in Footnote 4 to hold.
}

cleaved equals $x$. The probability that a protein molecule with $n$ connector-arm links to the gel will be released is $x^{n} . f_{n}{ }^{\circ}$ represents the amount of releasable protein containing $n$ connector arms relative to the total amount of releasable protein. If the distribution of the number of links to the gel were such that properties of the protein-linked gel could be approximated by a protein containing $\bar{n}$ links to the gel, where $\bar{n}$ is an average value for the number of crosslinks to the gel, then Eq. [2] should hold and a plot of $\log f_{\mathrm{r}}$ vs $\log x$ should be

$$
f_{\mathrm{r}}=x^{\bar{n}}
$$

linear. Such a plot (Fig. 4, inset) was constructed for trypsin using values of $x$ and $f_{\mathrm{r}}$ at equivalent times. The slope of the log $f_{\mathrm{r}}$ vs $\log x$ plot in the inset to Fig. 4 yields a value of 3.1 for $\bar{n}$.

The actual weight average value of the number of connector arms attached to releasable covalently bound trypsin was estimated by treating released trypsin with 2,4-dinitrofluorobenzene. This reagent forms acid-stable DNP derivatives with unblocked $\alpha$-amino and $\epsilon$-amino groups of proteins. Since released protein should have its $\alpha$ - amino and $\epsilon$-amino groups blocked in an amide linkage at the residues where connector arms were attached, only lysyl residues which had been linked to connector arms should give rise to free lysine after dinitrophenylation and acid hydrolysis. Comparison of the amino acid analysis of released protein after dinitrophenylation and acid hydrolysis (6.2 mol lysine/mol protein) to that of native trypsin treated in a similar manner $(2.8 \mathrm{~mol}$ lysine/mol protein) ${ }^{6}$ indicated an average of 3.4 lysyllinked connector arms per molecule of tryp$\sin$. A yield of $0.9 \mathrm{~mol} / \mathrm{mol}$ protein for $\alpha$-DNP amino acids is obtained with released trypsin in comparison to the yield of $0.8 \mathrm{~mol} / \mathrm{mol}$ protein obtained for native trypsin. This result is consistent with the view that trypsin was not linked to the gel via $\alpha$-amino

\footnotetext{
6 The incomplete dinitrophenylation of $\alpha$ - and $\epsilon$-amino groups of trypsin is probably due to our not using harsh enough conditions to expose completely all the buried amino groups during dinitrophenylation.
} 


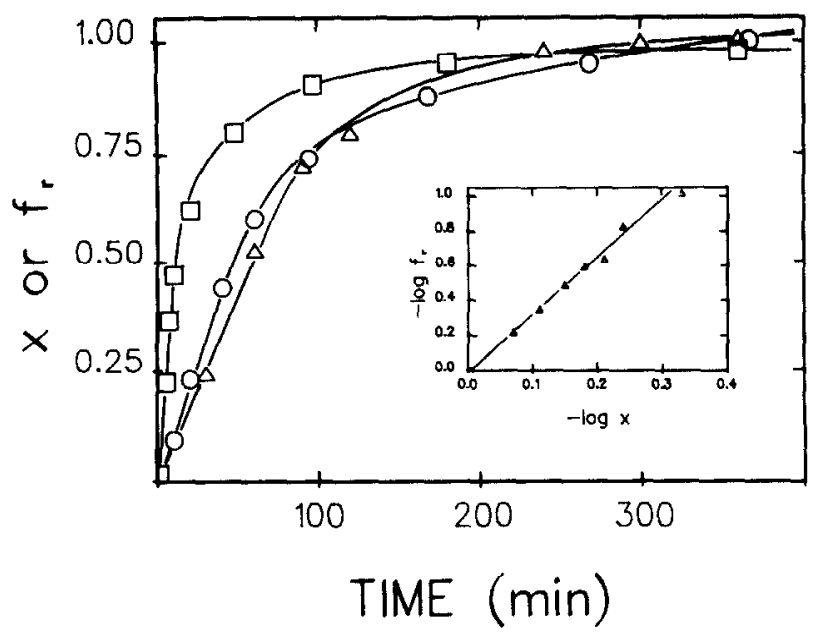

FIG. 4. Connector arm cleavage and the release of trypsin and myoglobin from trypsin-linked and myoglobin-linked PE-Agarose. The degree of connector arm cleavage, $x$, was obtained from the fraction of releasable HPPA and derivatives thereof that are released from glycine-linked PE-Agarose. The fraction, $f_{\mathrm{r}}$, of releasable trypsin that had been released from the gel was obtained by dividing the amount of protein released at a given time by the amount of protein released after $6 \mathrm{~h}$, after which time protein release essentially ceased. $(O, \triangle, \square)$ Values of $f_{\mathrm{r}}$ for trypsin and myoglobin and values of $x$, respectively. The values of $x$ and $f_{r}$ at equal times that were used to construct the $\log -\log$ plot in the inset were interpolated from the curves in this figure.

groups. $^{7}$ The value of 3.4 connector-arm links to the gel per molecule of trypsin obtained from this analysis, is similar to the value of $\bar{n}=3.1$ determined from the slope of the plot in Fig. $4 .^{8}$

The trypsin released from trypsin-linked PE-Agarose exhibited a specific catalytic activity similar to that of native trypsin. Interestingly, prior to its release with the glycine-imidazole buffer, the gel-bound trypsin had a specific catalytic activity which

\footnotetext{
${ }^{7}$ The failure of the $\mathrm{N}$-terminal $\alpha$-amino groups in trypsin to react with the $\mathrm{N}$-succinimidyl esters of the gel is not surprising. The N-terminal amino groups in trypsin appear to be buried and they also react with acetic anhydride much more slowly than lysyl amino groups (14).

${ }^{8}$ It should be noted that the difference between $\bar{n}$ and the weight average value of $n$ should be a function of the distribution of crosslinks. If all the trypsin molecules had the same number of crosslinks to the gel, $\bar{n}$ would of course equal the weight average value of $n$. Hypothetical $\log f_{\mathrm{r}}$ vs $\log x$ plots were generated assuming various distributions of crosshinks. These plots yielded values of $\bar{n}$ which like the observed value of $\vec{n}$ were somewhat less than the weight average value of the number of crosslinks.
}

was $180 \%$ that of the soluble trypsin from which the trypsin-linked gel was formed. The trypsin remaining on the gel after treatment with imidazole-glycine buffer also exhibited a similarly enhanced activity. The reason for this increased activity of immobilized trypsin has not been explored. There are many well-documented examples, however, of altered kinetic properties of enzymes linked to macromolecules (15).

In addition to imidazole-glycine, hydroxylamine at $\mathrm{pH} 7.0$ was found to be very effective in releasing covalently bound trypsin from the gel. The extent of trypsin release observed with hydroxylamine as judged from the appearance of active trypsin in the hydroxylamine solution was found to be similar to that observed with imidazole-glycine. Release of trypsin, however, was observed to be much faster $(10 \mathrm{~min}$ vs 4-6 h) with the hydroxylamine than with the glycine-imidazole solution. Hydroxylamine-mediated release of myoglobin from myoglobin-linked PE-Agarose was not studied, because of the complex time-dependent effects of hydroxylamine on the spectrum of myoglobin. 
Treatment of glycine-linked PE-Agarose with hydroxylamine results in the release of HPPA and derivatives thereof $(8.0 \mu \mathrm{mol} / \mathrm{ml}$ gel) in an amount similar (within 5\%) to that observed with imidazole-glycine. Interestingly, treatment of glycine-linked or trypsin-linked PE-Agarose with hydroxylamine also results in the release of about $23 \mu \mathrm{mol}$ NHS/ml gel. Release of NHS is not observed, however, when these ligand-linked PEAgarose gels are treated with imidazoleglycine buffer prior to treatment with hydroxylamine. Since NHS itself is stable in the imidazole-glycine buffer, and since NHS ester linkages are destroyed in the preparation of ligand-linked PE-Agarose, it is unlikely that the NHS liberated in the presence of hydroxylamine arises from $N$-succinimidyl esters. This extra NHS probably arises from the attack of hydroxylamine on one phenyl ester linkage of a connector arm to form a hydroxamate which then undergoes cyclization (to form NHS) and cleavage of the remaining phenyl ester linkage. This thesis is supported by the observation that upon reaction with $1 \mathrm{M}$ hydroxylamine at $\mathrm{pH} 7$, diphenyl succinate rapidly forms NHS in about $50 \%$ yield. ${ }^{9}$ Surprisingly, however, hydroxylamine treatment results in the release of $23 \mu \mathrm{mol}$ $\mathrm{NHS} / \mathrm{ml}$ of gel instead of the expected 2 $\mu \mathrm{mol} / \mathrm{ml}$ gel (i.e., one-fourth of the $8 \mu \mathrm{mol} / \mathrm{ml}$ gel of HPPA and derivatives thereof that is released from the gel by hydroxylamine). This result can be explained, however, if in its reaction with AECM-Agarose, BSPS were to crosslink a substantial fraction of the aminoethyl groups in AECM-Agarose. In such crosslinks, both oxyphenylpropionyl groups of BSPS would be linked to the gel via amide bonds which are not hydrolyzed in the imidazole-glycine or hydroxylamine solutions. Consistent with the existence of such crosslinks is the observation that the amount of HPPA (76 $\mu \mathrm{mol} / \mathrm{ml}$ gel) released upon hydrolysis of

\footnotetext{
${ }^{9}$ That is, the amount of NHS produced was observed to be one-fourth instead of one-half the amount of phenol released. The low yield of NHS is probably due to intermolecular attack by hydroxylamine on the remaining phenyl ester group of the intermediate before it can cyclize.
}

SEPE-Agarose with $5 \mathrm{M} \mathrm{NaOH}$ also is greater than the amount of HPPA derivatives released from the gel with imidazoleglycine or hydroxylamine. Furthermore, the observed yield of NHS $(23 \mu \mathrm{mol} / \mathrm{ml}$ gel) is not very different from the yield of NHS (one-fourth of 76 or $19 \mu \mathrm{mol} / \mathrm{ml}$ gel) one would predict by assuming that all of the HPPA released by the $\mathrm{NaOH}$ contains succinate ester linkages which exhibit reactivity toward hydroxylamine similar to that of diphenyl succinate.

Figure 5 illustrates the stability of myoglobin linked PE-Agarose in phosphate and Tris buffers at $25^{\circ}$ and indicates that the stability of the myoglobin-linked PEAgarose decreases with increasing $\mathrm{pH}$. Thus stirring the gel for 16 days with $0.1 \mathrm{M}$ phosphate buffer at $\mathrm{pH} 6.4$ results in the release of $11 \%$ of the myoglobin from the gel, whereas $21 \%$ of the myoglobin is released from the gel after 16 days in $0.1 \mathrm{M}$ phosphate buffer at $\mathrm{pH} 7.4,25^{\circ} \mathrm{C}$. As expected the stability of the gel could be increased further by lowering the temperature. Storage of the gel at $4^{\circ} \mathrm{C}$ for 1 month under $0.1 \mathrm{M}$ phosphate buffer at $\mathrm{pH} 6.4$ results in release from the gel of less than $5 \%$ of the myoglobin. Furthermore, no significant change $(<10 \%)$ was observed in the amount of protein which could be released upon treatment with imidazole-glycine buffer after storage for 1 month at $\mathrm{pH} 6.4,4^{\circ} \mathrm{C}$. Under similar conditions of storage, $13 \%$

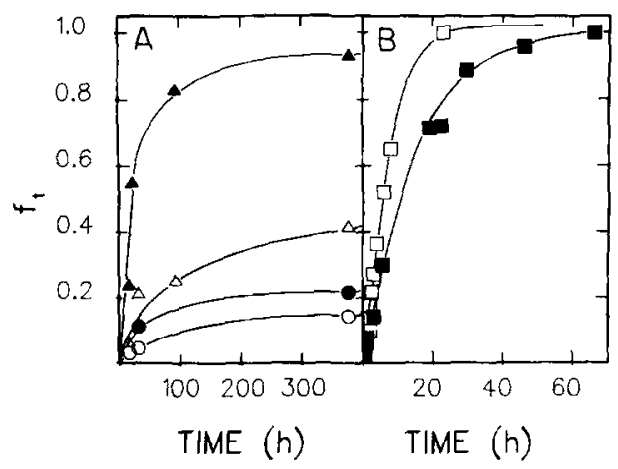

Fig. 5. Time-dependent increase in the fraction $\left(f_{\mathrm{t}}\right)$ of the total myoglobin linked to the gel that is released into buffers at $25^{\circ} \mathrm{C}$. (A) $\mathrm{pH} 6.4,0.1 \mathrm{M}$ phosphate (O); pH 7.4, 0.1 M phosphate (O); pH 7.4, 0.1 M Tris $(\triangle) ; \mathrm{pH} 8.2,0.1 \mathrm{M}$ Tris (A). (B) $\mathrm{pH} 8.2,1.0 \mathrm{M}$

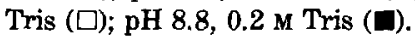


of the phenyl ester linkages were found to be cleaved as judged from the quantity of HPPA derivatives released from glycinelinked PE-Agarose. If prolonged storage of a ligand-linked PE-Agarose is necessary, increased stability during storage might be obtained by storing lyophilized gel or storing the gel under an organic solvent or an aqueous organic solvent mixture.

The data depicted in Fig. 5 also show that myoglobin is released from the gel at $\mathrm{pH} 7.4$ faster in the presence of $0.1 \mathrm{M}$ Tris buffer than in the presence of $0.1 \mathrm{M}$ phosphate buffer. Interestingly, the rates of release of myoglobin in the Tris buffers (pH 8-9) are sufficient to warrent use of these buffers to release covalently bound protein. For example, treatment of myoglobin-linked PE-Agarose with $1 \mathrm{M}$ Tris buffer at $\mathrm{pH} 8.2$ for $24 \mathrm{~h}$ results in release of essentially all of the myoglobin from the gel (Fig. 5).

The SEPE-Agarose described in this work should extend the usefulness of succinimidyl esters of agarose previously described by Cuatrecasas and Parikh (4). In addition to its potential usefulness in affinity chromatography and immunoabsorption, in cases where it is difficult to release absorbed material, SEPE-Agarose derivatives might be useful for screening for the presence of compounds in extracts of biological material which interact strongly with an immobilized physiologically important compound. With conventional affinity supports, it would be difficult to characterize material which interacts with the immobilized ligand too strongly to be conveniently removed from the support. SEPE-Agarose derivatives which are linked to active site-directed reagents could prove useful in determination of structure-function relationships for proteins. Modified protein, after being linked to a SEPEAgarose derivative of an active site-directed reagent, could be digested with a protease such as trypsin, leaving only the active site peptide attached to the agarose support. The active site peptide then could be released from the support for further study of its properties and its structure. Finally, derivatives of SEPE-Agarose which react or interact specifically with material on cell surfaces should prove useful in the purification of cell surface components.

\section{REFERENCES}

1. Schramm, H. J., AND DülfFer, Th. (1976) Hoppe-Seyler's Z. Physiol. Chem. 357, 477-479.

2. Fasold, H., Baumert, H., AND FiNK, G. (1977) in Advances in Experimental Medicine and Biology (Friedman, M., ed.), Vol. 86A, pp. 207-214, Plenum, New York.

3. Daub, G. H., AND Johnson, W. S. (1963) Org. Synth. Coll. 4, 390.

4. Cuatrecasas, P., and Parikh, 1. (1972) Biochemistry 11, 2291-2299.

5. Rudinger, J., AND RuEgG, U. (1973) Biochem. $J$. 133, 538-539.

6. Cramer, F. (1960) Angew. Chem, 72, 236-249.

7. Inman, J. K., AND DinTzis, H. M. (1969) Biochemistry 8, 4074-4082.

8. Spackman, D. H., Stein, W. H., and Moore, S. (1958) Anal. Chem. 30, 1190-1206.

9. Erlanger, B. F., Kokowsky, N., AND Cohen, W. (1961) Arch. Biochem. Biophys. 95, 271-278.

10. Fraenkel-Conrat, H., Harris, J. I., and Levy, A. L. (1955) Methods Biochem. Anal. $2,359-425$.

11. Steven, F. S. (1962) J. Chromatogr. 8, 417-418.

12. Kirsch, J. F., AND JenCKs, W. P. (1964) J. Amer. Chem. Soc. 86, 837-846.

13. KIRSCH, J. F., AND Jencks, W. P. (1964) J. Amer. Chem. Soc. 86, 833-837.

14. Labouesse, J., AND Gervais, M. (1967) Eur. $J$. Riochem, 2, 215-223,

15. Katchalski, E., Silman, I., and Goldman, R. (1971) Advan. Enzymol. 34, 445-536. 